\title{
Plant cell wall dynamics and wall-related susceptibility in plant-pathogen interactions
}

\author{
Daniela Bellincampi, Felice Cervone and Vincenzo Lionetti* \\ Dipartimento di Biologia e Biotecnologie "Charles Darwin," Sapienza Università di Roma, Rome, Italy
}

\section{Edited by:}

Jean-Pierre Metraux, Université de Fribourg, Switzerland

\section{Reviewed by:}

Jurriaan Ton, University of Sheffield, UK

Simone Ferrari, Sapienza Università di Roma, Italy

\section{${ }^{*}$ Correspondence:}

Vincenzo Lionetti, Dipartimento di Biologia e Biotecnologie "Charles Darwin," Sapienza Università di Roma, Rome 00185, Italy

e-mail: vincenzo.lionetti@uniroma1.it
The cell wall is a dynamic structure that often determines the outcome of the interactions between plants and pathogens. It is a barrier that pathogens need to breach to colonize the plant tissue. While fungal necrotrophs extensively destroy the integrity of the cell wall through the combined action of degrading enzymes, biotrophic fungi require a more localized and controlled degradation of the cell wall in order to keep the host cells alive and utilize their feeding structures. Also bacteria and nematodes need to degrade the plant cell wall at a certain stage of their infection process, to obtain nutrients for their growth. Plants have developed a system for sensing pathogens and monitoring the cell wall integrity, upon which they activate defense responses that lead to a dynamic cell wall remodeling required to prevent the disease. Pathogens, on the other hand, may exploit the host cell wall metabolism to support the infection. We review here the strategies utilized by both plants and pathogens to prevail in the cell wall battleground.

Keywords: cell wall, cell wall integrity, host cell wall metabolism reprogramming, plant defense, susceptibility factors

\section{INTRODUCTION}

Phytopathogenic fungi, bacteria, and nematodes infect, grow and reproduce themselves on the plant tissues and, at least at the early stages of infection, require breaking the integrity of the host cell wall. Beyond the cuticle layer, the interaction with the plant cell wall and the extent of the wall degradation are determined by the lifestyle of the pathogen. Plants perceive a diverse set of microbial molecules referred to as microbial/pathogen associated molecular patterns (MAMPs/PAMPs; Boller and He, 2009) through high-affinity cell surface pattern recognition receptors (PRRs) leading to intracellular signaling, transcriptional reprogramming, and biosynthesis of defense metabolites that limit the microbial infection (Dangl et al., 2013). Emerging evidences indicate that plant cells also exploit sophisticated mechanisms of sensing the alteration of cell wall integrity (CWI) during biotic stress (Hamann, 2012; Pogorelko et al., 2013a). For instance, they perceive endogenous molecules produced in damaged tissues (the so-called damage-associated molecular patterns, or DAMPs) through membrane receptors (Ferrari et al., 2013). The loss of CWI induced by pathogens activates a variety of defense responses including a cell wall remodeling required to prevent the disease. To escape recognition, pathogens produce effector proteins that counteract the plant defenses (Giraldo and Valent, 2013) and, sometimes, exploit the host cell wall metabolism to favor the infection process (Cantu et al., 2008b).

\section{CELL WALL DYNAMICS DURING INFECTION BY MICROBIAL PATHOGENS}

Infection by fungal necrotrophs is a complex process that includes conidial attachment, germination, host penetration, lesion formation and expansion, and tissue maceration followed by sporulation (Prins et al., 2000). Penetration may be achieved by degrading the external cuticle through the action of cutinases and lipases (Laluk and Mengiste, 2010). The role of the cuticle in plant defense is discussed elsewhere (Chassot and Metraux, 2005; Chassot et al., 2007). Once penetrated the cuticle, necrotrophs have a spatial and temporal strategy of attacking the plant cell wall by producing several cell wall degrading enzymes (CWDEs) belonging to multiple families (Figure 1A). The diversity of these enzymes mirrors the structural complexity and the dynamics of the cell wall as well as the lifestyle and host adaptation of the pathogen (King et al., 2011). The extensive degradation of cell wall polysaccharides by necrotrophs is sensed by plants. The leucine-rich repeat receptorlike kinase (LRR-RLK) ERECTA (ER) and the heterotrimeric G-protein are involved in cell wall remodeling during Arabidopsis defense response against Plectosphaerella cucumerina and probably control CWI (Llorente et al., 2005; Sanchez-Rodriguez et al., 2009). The impairment of cellulose synthases involved in secondary cell wall deposition is also a mechanism of sensing CWI and enhances disease resistance of Arabidopsis to P. cucumerina and Ralstonia solanacearum (Hernandez-Blanco et al., 2007).

One of the strategies used by plants to limit the degradation of the cell wall polysaccharides by microbial CWDEs is the production of proteinaceous inhibitors (Figures 1A,B). Polygalacturonases (PGs) are pathogenicity factors produced at the earlier stages of a microbial infection that depolymerize the homogalacturonan (HG), i.e., the main component of pectin in dicots but also present in monocots (Caprari et al., 1993; D'Ovidio et al., 2004). Against microbial and insect PGs, plants produce cell wall-associated polygalacturonase-inhibiting proteins (PGIPs; Spadoni et al., 2006). The over expression of PGIPs improves the resistance to fungal and bacterial necrotrophs in different plants (Aguero et al., 2005; Ferrari et al., 2012). The PG-PGIP interaction results in the accumulation of elicitor-active oligogalacturonides 

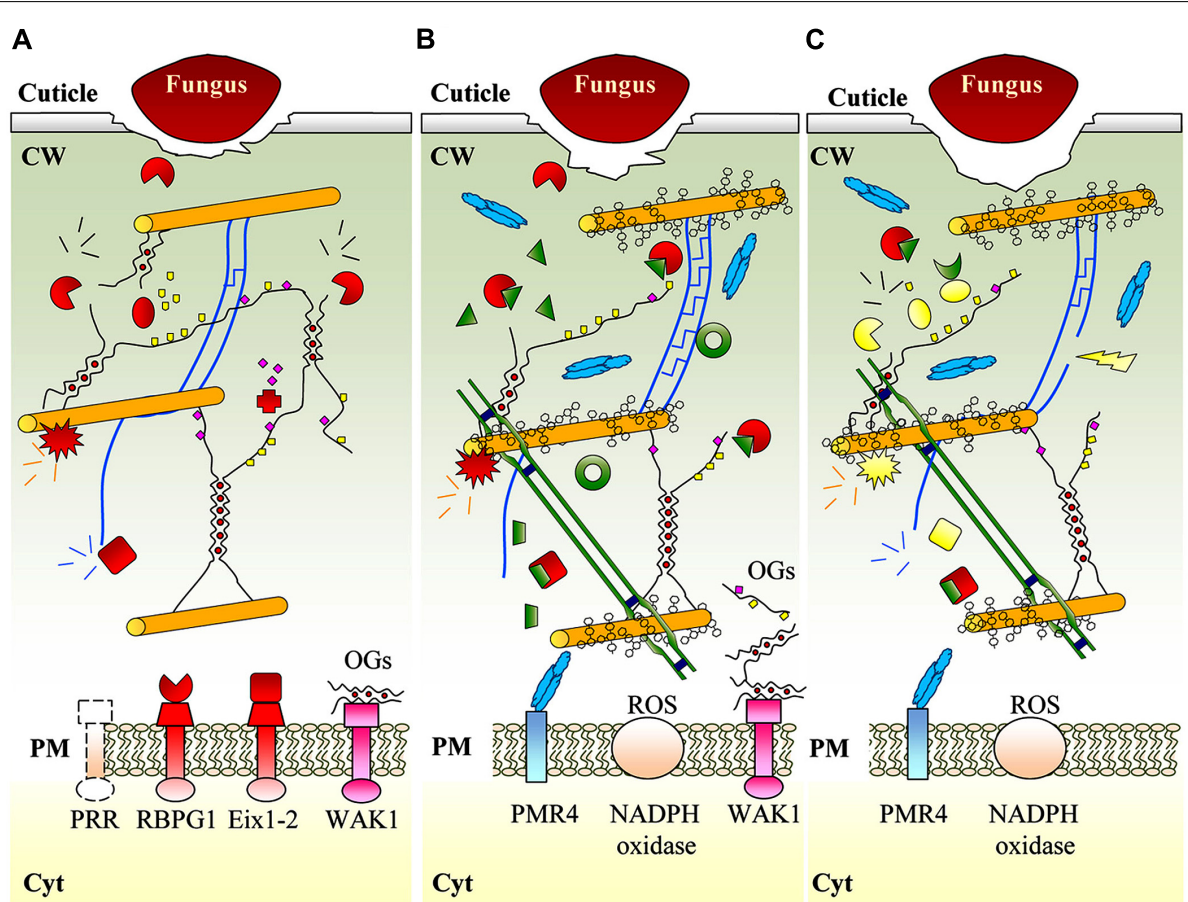

Cyt

$$
\text { Cyt }
$$

\section{FUNGAL ENZYMES}

Hemicellulase

PME

$\mathrm{AE}$

PLANT DEFENCE PROTEINS

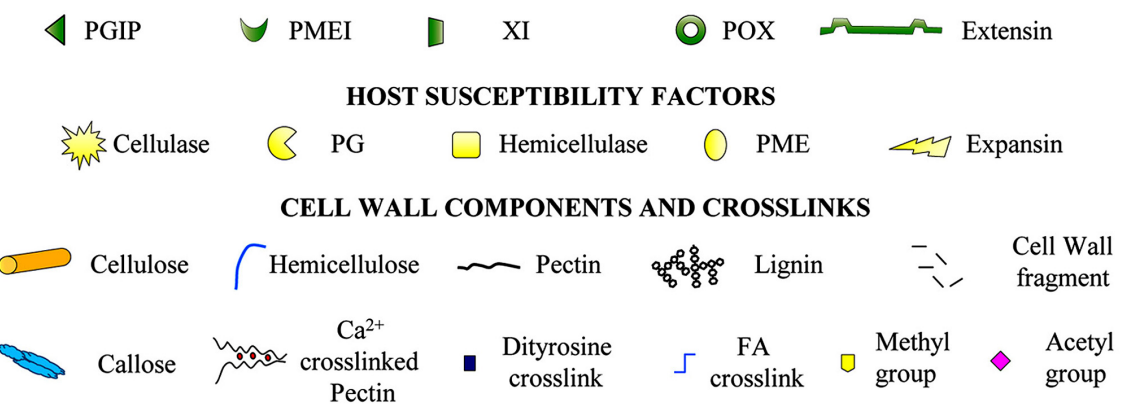

FIGURE 1 | Cell wall dynamics during necrotrophs invasion. (A) Necrotrophic fungi secrete a large arsenal of cell wall degrading enzymes (CWDEs) like PGs, hemicellulases and cellulases, assisted by PMEs and AEs in the apoplastic space to degrade cell wall polymers and facilitate the availability of nutrients. PGs and EIXs have been proposed to function as PAMPs recognized by the membrane receptors RBPG1 and Eix1 or 2, respectively. (B) As first line of defense, plants produce a variety of CWDE inhibitors to hinder degradation by microbial CWDEs. For instance, the inhibition of PG degrading activity by PGIPs induces the accumulation of elicitor-active pectin fragments (OGs) perceived by WAK1 receptors. It cannot be excluded the presence of other not yet identified receptors sensing damage of other cell wall components. The perception of cell wall damage triggers specific signaling pathways activating defense responces aimed to reinforce cell wall structure. The more evident defense strategies are callose and lignin deposition, induction of peroxidases/ROS-mediated crosslinks between cell wall structural proteins and polysaccharides. (C) Necrotrophs force plants to cooperate in disease exploiting plant cellulases, expansins, PGs and PMEs as susceptibility factors. PM, plasma membrane; CW, cell wall; Cyt, cytoplasm; OGs, oligogalacturonides; WAK1, wall associated kinase 1; AEs, acetyl esterases; PGs, polygalacturonases; EIXs, ethylen induced xylanases; PME, pectin methylesterases; PMEI, pectin methylesterase inhibitor; FA, ferulic acid; Eix1-2, receptors of ethylene induced xylanases; RBPG1,

Responsiveness to Botrytis PolyGalacturonase $1 ; \mathrm{Ca}^{2+}$, calcium ions; $\mathrm{XI}$, xylanase inhibitor; PRR, pattern recognition receptor; POX, peroxidase; $\mathrm{ROS}$, reactive oxygen species.
(OGs) that are perceived in Arabidopsis by the receptor Wall Associated Kinase 1 (WAK1; Brutus et al., 2010) to activate the plant immune responses (Ferrari et al., 2013). Accumulation and sensing of OGs in response to pathogens is critical for monitoring the pectin integrity and, in general, a tissue injury (De Lorenzo et al., 2011). Alteration of pectin integrity caused by the expression of PGII from Aspergillus niger in tobacco and Arabidopsis causes a constitutive activation of defense genes and resistance against Botrytis cinerea (Ferrari et al., 2008). Recently, B. cinerea and A. niger PGs have been proposed to function themselves as PAMPs recognized by the Arabidopsis Receptor-Like Responsiveness to Botrytis PolyGalacturonase 1 (RBPG1) belonging to 
a super clade of LRR receptor-like proteins (RLPs; Zhang et al., 2014).

Xylan is the major hemicellulose polymer in cereals. To counteract xylan degradation by microbial endoxylanases, graminaceous monocots produce the Triticum aestivum xylanase inhibitor (TAXI), the xylanase inhibitor protein (XIP) and the thaumatinlike xylanase inhibitor (TL-XI; Bellincampi et al., 2004; Juge, 2006). The constitutive expression of TAXI-III in wheat reduces susceptibility to Fusarium graminearum (Moscetti et al., 2013). On the other hand, fungal xylanases function as PAMPs by eliciting defense responses and promoting necrosis (Noda et al., 2010; Sella et al., 2013). Ethylene inducing xylanases (EIXs) produced by Trichoderma species are perceived in tomato, by two specific LRR-RLPs receptors, LeEix1 and LeEix2 (Ron and Avni, 2004). Both receptors bind Eixs, while only LeEix2 mediates defense responses. LeEix1 heterodimerizes with LeEix2 upon application of the Eixs and attenuates Eix-induced internalization and signaling of the LeEix2 receptor (Bar et al., 2010). Xyloglucan, i.e., the main hemicellulosic polysaccharide in the primary walls of dicots and non-graminaceous monocots, is degraded by microbial xyloglucan-specific endoglucanases (XEGs). Fungal XEGs are inhibited by xyloglucan endoglucanase inhibiting proteins (XEGIPs), which so far have been characterized in tomato, carrot and tobacco (Juge, 2006).

Reinforcement of the cell wall is initiated at the pathogen penetration sites in response to cell wall damage (Figure 1B). Deposition of callose by the callose synthase PMR4 occurs upon infection of Arabidopsis with P. cucumerina and Alternaria brassicicola (Ton and Mauch-Mani, 2004; Flors et al., 2008). Callose deposition is triggered by PAMPs and DAMPs, is affected by environmental conditions and requires the apoplastic accumulation of the hydrolysis products of glucosinolates or benzoxazinoid metabolites (Galletti et al., 2008; Ahmad et al., 2011; Luna et al., 2011).

Deposition of lignin has been associated to resistance of cotton to Verticillium dahliae and of Camelina sativa to Sclerotinia sclerotiorum (Xu et al., 2011; Eynck et al., 2012). Lignin makes the cell wall more resistant to CWDEs and also prevents the diffusion of pathogen-produced toxins (Sattler and Funnell-Harris, 2013). The cell wall may also be reinforced by cross-links and insolubilization of structural proteins like the hydroxyproline-rich glycoproteins (HRGPs) by peroxidasemediated isodityrosine linkages formed in response to pathogen attach (Deepak etal., 2010). Plant peroxidases catalyze crosslinks between phenolic compounds in the secondary walls and between polysaccharides and ferulic acid (FA) upon attack by necrotrophs (Passardi et al., 2004). Crosslinks between FA and polysaccharides enhance the recalcitrance of the cell wall to digestion by microbial CWDEs and the overall resistance to fungi (Bily et al., 2003). On the other hand, fungal FA esterases may shear FA from the cell wall polysaccharides (Udatha et al., 2012).

The activities of pectin methyl esterases (PMEs) from both plants and pathogens and the degree and pattern of pectin methyl esterification are critical for the outcome of plant-pathogen infections (Lionetti etal., 2012). The cell walls containing highly methylesterified pectin are somewhat protected against the action of microbial PGs and pectate lyases (PLs; Arancibia and Motsenbocker, 2006). PMEs, which remove methyl esters from pectin, are controlled by PME inhibitor proteins (PMEIs) either during growth and development (Raiola et al., 2004; Rocchi et al., 2011; Reca et al., 2012) and during plant-pathogen interactions (Lionetti et al., 2012). The biochemical and structural bases of the enzyme/inhibitor interaction have been elucidated (Mattei et al., 2002; Di Matteo et al., 2005). Arabidopsis over expressing PMEIs have a lower level of PME activity, a higher degree of pectin esterification and a concomitant reduced susceptibility to $B$. cinerea and Pectobacterium carotovorum (Lionetti et al., 2007; Raiola et al., 2011). The ectopic expression in wheat of a PME inhibitor from kiwi reduces the susceptibility to F. graminearum and Bipolaris sorokiniana (Volpi et al., 2011). The transcription factor MYB46 which affect the secondary cell wall biosynthesis (Zhong et al., 2007), regulates the expression of genes encoding several cell wall proteins including PMEI and mediates disease susceptibility of Arabidopsis to B. cinerea (Ramirez et al., 2011). Recently, jasmonic acid has been proposed to modulate the degree of methylesterification in potato to protect pectin degradation by PLs produced by Dickeya dadantii (Taurino et al., 2014). Acetylation of the cell wall polysaccharides is also a determinant of plant-pathogen interaction. An Arabidopsis mutant with reduced acetylation displays increased tolerance to B. cinerea (Manabe et al., 2011). Arabidopsis and Brachypodium distachyon plants expressing xylan or pectin acetylesterases from $A$. nidulans activate specific defense responses and are more resistant to $B$. cinerea and B. sorokiniana (Pogorelko et al., 2013b).

Biotrophic and hemi-biotrophic fungi acquire nutrients from the host cells without causing their death. They often attack the plant surface and penetrate the external barriers by developing appressoria and exploiting the mechanical pressure (Wilson and Talbot, 2009). In order to breach the host cuticle they also secrete oxidases, esterases, cutinases, and lipases (Feng et al., 2011). Small amounts of CWDEs associated with local softening and loosening of plant cell walls are produced by biotrophic microorganisms (Zhao et al., 2013) (Figure 2A). Plants contrast invasion of biotrophs by the apposition of "papillae," cell wall thickening early produced at the site of pathogen penetration (Figure 2B). Papillae contain callose, as most abundant constituent, cellulose, hemicelluloses, pectins, lignin, and structural proteins such as arabinogalactan proteins and HRGPs (Aist, 1976; Celio et al., 2004; Voigt, 2014). Transgenic Arabidopsis plants overexpressing the callose synthase PMR4 show an early and elevated deposition of callose at the sites of penetration which prevents the haustoria formation and further penetration by Golovinomyces cichoracearum and Blumeria graminis (Ellinger et al., 2013). Papillae are also the sites where antimicrobial peptides, toxic secondary metabolites and reactive oxygen species (ROS) accumulate and contribute to plant resistance (Bednarek et al., 2009; Daudi et al., 2012). Lignification and cross-links of proteins in the papillar cell wall may entrap the penetration peg of biotrophic fungi and render the cell wall more resistant to the mechanical pressure exerted by fungal appressoria (Bechinger et al., 1999; O’Brien et al., 2012). Lignin downregulation may also activate defense responses and increases the resistance to the hemibiotroph Colletotrichum trifolii in alfalfa (Medicago sativa L.) (Gallego-Giraldo et al., 2011). 


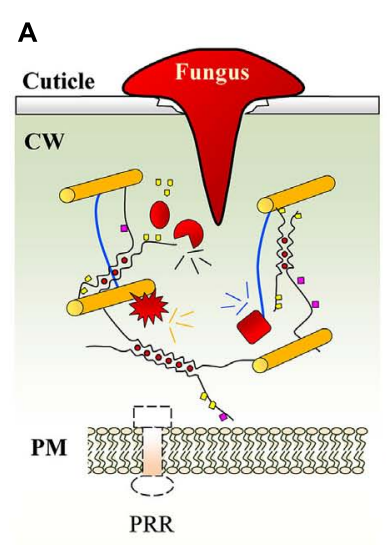

Cyt

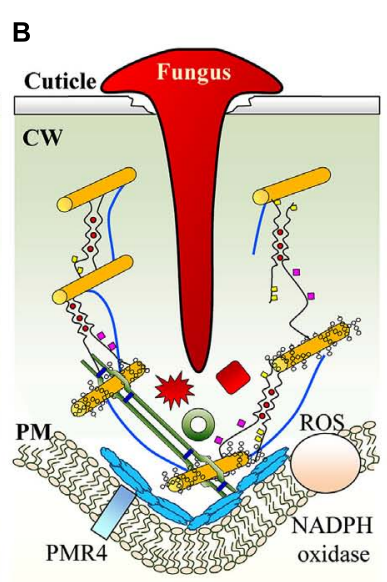

Cyt

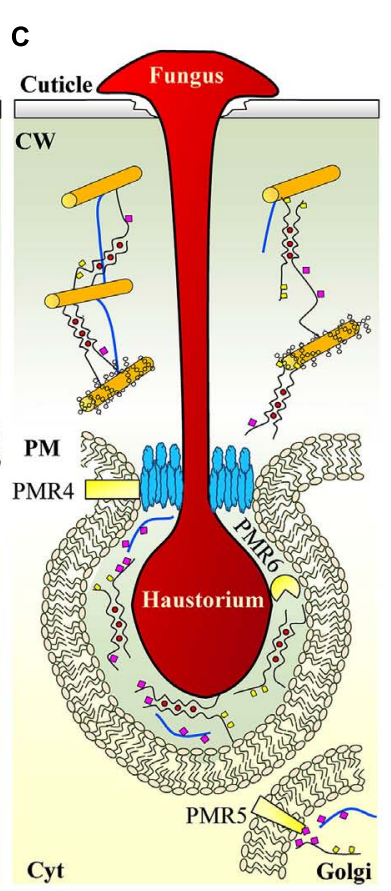

Cyt

\section{FUNGAL ENZYMES}

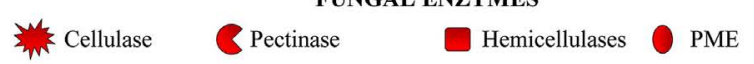

PLANT DEFENCE PROTEINS

HOST SUSCEPTIBILITY FACTORS

POX
CELL WALL COMPONENTS AND CROSSLINKS
Cellulose

FIGURE 2 | Cell wall dynamics in plant-biotrophic fungi interaction. (A) Biotrophic fungi use appressorial mechanical pressure and secrete cell wall degrading enzymes to penetrate plant cell wall. (B) Plants perceive fungal biotrophs penetration with not yet identified receptors and respond with "papillae" apposition between cell wall and plasma membrane. Papillae, in addition to new cell wall material are also sites of accumulation of ROS possibly involved in cell wall reinforcement. (C) At a later stage of infection, fungus forms the haustorium feeding organ invaginated into the host membranes and plant cell wall. Biotrophs locally affect cell wall metabolism by induction of susceptibility factors (callose synthase PMR4, $O$-acetyltransferase PMR5 and pectate lyase PMR6) to modify the extrahaustorial matrix to improve the accessibility of nutrients or to ensure the mechanical stability of the haustorium. PM, plasma membrane; CW, cell wall; Cyt, cytoplasm; PG, polygalacturonase; PME, pectin methylesterase; $P R R$, pattern recognition receptor; POX, peroxidase; ROS, reactive oxygen species.
A reduced cellulose content by mutation of cellulose synthase CESA3, involved in primary cell wall formation, leads to production of lignin, and makes Arabidopsis more resistant to different powdery mildew pathogens (Ellis and Turner, 2001; Ellis et al., 2002; Cano-Delgado et al., 2003). RLKs belonging to the Catharanthus roseus (CrRLK)-like protein family are implicated in CWI mechanisms. Among these, THESEUS1 (THE1) is required for lignification in response to inhibition of cellulose biosynthesis (Hematy et al., 2007).

Alteration of pectin integrity can trigger plant immunity also against hemibiotrophs (Ferrari et al., 2008; Bethke et al., 2013). Arabidopsis PMEs, triggered by a Jasmonic acid dependent pathway, contribute to plant immunity against Pseudomonas syringae(Bethke et al., 2013).

\section{MICROBIAL PATHOGENS EXPLOIT THE HOST CELL WALL METABOLISM TO FACILITATE PATHOGENESIS}

Necrotrophs can force plants to cooperate in disease by altering the host cell wall and favoring the cell wall accessibility to CWDEs (Hok et al., 2010; Figure 1C). The Arabidopsis AtPME3 is induced upon infection with B. cinerea and P. carotovorum and functions as susceptibility factor required for the initial colonization of the host tissue (Raiola et al., 2011). A PG (LePG) and expansin (LeExp1) cooperatively contribute to cell wall loosening during tomato ripening; their expression is induced by necrotrophic pathogens to successfully infect fruits (Cantu et al., 2009). Transgenic tomato fruits with suppressed expression of LePG and LeExp1 exhibit a reduced susceptibility to $B$. cinerea (Cantu et al., 2008a). Silencing of two putative endo $\beta$-1,4-endoglucanases, involved in the 
hydrolysis of cellulose or hemicellulose during ripening, cause a reduced susceptibility of tomato fruits to $B$. cinerea (Flors et al., 2007).

Biotrophic fungi, at a later stage of infection, produce a limited and localized degradation of the cell wall in the epidermal or mesophyll cells (Herbert et al., 2004). On the other hand, they form intracellular structures, like the "haustoria," i.e., feeding organs invaginated into the host membranes to acquire nutrients. Biotrophs need to avoid the host defense responses and carefully regulate the cell-wall degradation at the border of their feeding structures to allow fungal accommodation and haustorium function (Figure 2C). A screening for Arabidopsis powdery mildew-resistant mutants allowed isolating two pectinrelated genes, PMR5 and PMR6 which are pathogen-induced and required for susceptibility to G. cichoracearum and G. orontii (Vogel et al., 2002, 2004). PMR5 encodes a protein with unknown function that shares sequence similarity with genes encoding polysaccharide $O$-acetyltransferase (Gille and Pauly, 2012). Therefore, acetylation may be a host susceptibility mechanism that is reprogrammed by biotrophs during infection. PMR6 encodes a putative PL that is, possibly, recruited by the fungi as a susceptible factor to reduce $\mathrm{Ca}^{++}$-pectate domains at the level of haustoria-plasma membrane and facilitate cell wall porosity and accessibility of host nutrients (Vogel et al., 2002). Callose deposition may also work in favor of the pathogen by contributing to the stability and function of the haustoria and acting as a barrier that renders haustoria less susceptible to toxic metabolites that are produced by the host and accumulate in the site of infection (Jacobs et al., 2003). On the other hand, callose may limit the diffusion of pathogen-derived elicitors, thus reducing the activation of defense responses (Underwood, 2012).

Many bacterial pathogens utilize a type III secretion system to inject effector proteins directly into the host cytoplasm and manipulate the host cellular activities to their own advantage (Buttner and He, 2009). The effector AvrPto of P. syringae suppresses a set of Arabidopsis genes that encode cell wall-related defense proteins such as HRGPs (Hauck et al., 2003).

\section{CELL WALL DYNAMICS IN PLANT INTERACTIONS WITH NEMATODES AND VIRUSES}

Changes in the cell wall metabolism occur during plant infection by nematodes (Barcala et al., 2010; Bohlmann and Sobczak, 2014). Like biotrophic pathogens, root-knot and cyst nematodes need to establish feeding structures inside the plant tissue to allow the uptake of nutrients (Davis et al., 2004; Williamson and Kumar, 2006). This process is assisted by the secretion of CWDEs such as pectinases and cellulases produced by the nematodes, (Vanholme et al., 2004; Davis et al., 2008) and by the local expression of host proteins like expansins and cellulases (Wieczorek et al., 2006, 2008). The sugar beet cyst nematode Heterodera schactii infects Arabidopsis roots and exploits the host-encoded AtPME3. Transgenic plants overexpressing AtPME3 exhibit an increased susceptibility to the nematode. It has been proposed that AtPME3 locally reduces the pectin esterification and improves the cell wall loosening of pre-syncytial cells during the early stages of syncytium formation (Hewezi et al., 2008).
Callose deposition at the level of plasmodesmata (PD) limits the cell-to-cell spreading of plant viruses. Due to the small diameter of the PD pore, some viruses utilize the viral movement proteins (MPs) to modify the PD size exclusion limit. Specific interactions of viral MPs with PME are often required (Chen et al., 2000). In addition to MP-PME interaction, the PME-dependent formation of methanol has also been reported to be important for viral cellto-cell movement (Dorokhov et al., 2012; Komarova et al., 2014). The overexpression of PME inhibitor proteins in tobacco and Arabidopsis contrasts the cell-to-cell and systemic movement of tobamoviruses (Lionetti et al., 2013).

\section{CONCLUSION}

The cell wall is the battleground where plants and pathogens attempt to prevail by implementing contrasting wall-reinforcing and wall-weakening strategies. When pathogens start degrading the plant cell wall components, plants are capable of perceiving the loss of wall integrity and subsequently activate the defense signaling pathways. Pathogens try to escape the plant defenses and sometimes take advantage of the host cell wall metabolism to facilitate their entry into the tissue. These dynamic processes vary according to the lifestyle of the pathogen and the type of plant pathogen interaction. While necrotrophy involves a strong and diffused molecular warfare that may provoke extended lesions of the tissue, during biotrophy the battle involves a weaker cell wall degradation mainly localized at the point of penetration and at the level of the feeding apparatus. Perception of cell wall damage as well as the pathogen- and host-induced cell wall remodeling occurs in both cases. The damage of specific cell wall polysaccharides during infection may be perceived by receptors as THE1, ER and WAK1. Plants may also rely on the recognition of CWDEs by LRR-RLPs receptors, as RBPG1 and LeEIX1-2. Cell wall fragments may be released during infection and sensed as damage signals. Analysis of cell wall mutants has shed light on the relationship between cell wall remodeling and plant response to pathogens. The expression of endogenous and microbial CWDEs and their inhibitors is also a valuable approach for studying the dynamics of the cell wall during plantpathogen interactions as well as a strategy to improve plant protection.

\section{ACKNOWLEDGMENTS}

We would like to apologize to those people whose relevant publications could not be cited because of space constraints. This research was supported by the European Research Council (ERC Advanced Grant, 233083).

\section{REFERENCES}

Aguero, C. B., Uratsu, S. L., Greve, C., Powell, A. L. T., Labavitch, J. M., Meredith, C. P., et al. (2005). Evaluation of tolerance to pierce's disease and botrytis in transgenic plants of Vitis vinifera L. expressing the pear PGIP gene. Mol. Plant Pathol. 6, 43-51. doi: 10.1111/j.1364-3703.2004.00262.x

Ahmad, S., Veyrat, N., Gordon-Weeks, R., Zhang, Y. H., Martin, J., Smart, L., et al. (2011). Benzoxazinoid metabolites regulate innate immunity against aphids and fungi in maize. Plant Physiol. 157, 317-327. doi: 10.1104/pp.111.180224

Aist, J. R. (1976). Papillae and related wound plugs of plant cells. Annu. Rev. Phytopathol. 14, 145-163. doi: 10.1146/annurev.py.14.090176.001045

Arancibia, R. A., and Motsenbocker, C. E. (2006). Pectin methylesterase activity in vivo differs from activity in vitro and enhances polygalacturonase-mediated 
pectin degradation in tabasco pepper. J. Plant Physiol. 163, 488-496. doi: 10.1016/j.jplph.2005.06.022

Bar, M., Sharfman, M., Ron, M., and Avni, A. (2010). BAK1 is required for the attenuation of ethylene-inducing xylanase (Eix)-induced defense responses by the decoy receptor LeEix1. Plant J. 63, 791-800. doi: 10.1111/j.1365-313X.2010.04282.x

Barcala, M., Garcia, A., Cabrera, J., Casson, S., Lindsey, K., Favery, B., et al. (2010). Early transcriptomic events in microdissected Arabidopsis nematode-induced giant cells. Plant J. 61, 698-712. doi: 10.1111/j.1365-313X.2009.04098.x

Bechinger, C., Giebel, K. F., Schnell, M., Leiderer, P., Deising, H. B., and Bastmeyer, M. (1999). Optical measurements of invasive forces exerted by appressoria of a plant pathogenic fungus. Science 285, 1896-1899. doi: 10.1126/science.285.5435.1896

Bednarek, P., Pislewska-Bednarek, M., Svatos, A., Schneider, B., Doubsky, J., Mansurova, M., et al. (2009). A glucosinolate metabolism pathway in living plan cells mediates broad-spectrum antifungal defense. Science 323, 101-106. doi $10.1126 /$ science. 1163732

Bellincampi, D., Camardella, L., Delcour, J. A., Desseaux, V., D’Ovidio, R., Durand A., et al. (2004). Potential physiological role of plant glycosidase inhibitors. Biochim. Biophys. Acta 1696, 265-274. doi: 10.1016/j.bbapap.2003.10.011

Bethke, G., Grundman, R. E., Sreekanta, S., Truman, W., Katagiri, F., and Glazebrook, J. (2013). Arabidopsis pectin methylesterases contribute to immunity against pseudomonas syringae. Plant Physiol. 164, 1093-1107. doi: 10.1104/pp.113.227637

Bily, A. C., Reid, L. M., Taylor, J. H., Johnston, D., Malouin, C., Burt, A. J., et al. (2003). Dehydrodimers of ferulic acid in maize grain pericarp and aleurone: resistance factors to Fusarium graminearum. Phytopathology 93, 712-719. doi 10.1094/PHYTO.2003.93.6.712

Bohlmann, H., and Sobczak, M. (2014). The plant cell wall in the feeding sites of cyst nematodes. Front. Plant Sci. 5:89. doi: 10.3389/fpls.2014.00089

Boller, T., and He, S. Y. (2009). Innate immunity in plants: an arms race between pattern recognition receptors in plants and effectors in microbial pathogens. Science 324, 742-744. doi: 10.1126/science.1171647

Brutus, A., Sicilia, F., Macone, A., Cervone, F., and De Lorenzo, G. (2010). A domain swap approach reveals a role of the plant wall-associated kinase 1 (WAK1) as a receptor of oligogalacturonides. Proc. Natl. Acad. Sci. U.S.A. 107, 9452-9457. doi: 10.1073/pnas.1000675107

Buttner, D., and He, S. Y. (2009). Type III protein secretion in plant pathogenic bacteria. Plant Physiol. 150, 1656-1664. doi: 10.1104/pp.109. 139089

Cano-Delgado, A., Penfield, S., Smith, C., Catley, M., and Bevan, M. (2003). Reduced cellulose synthesis invokes lignification and defense responses in Arabidopsis thaliana. Plant J. 34, 351-362. doi: 10.1046/j.1365-313X.2003.01729.x

Cantu, D., Blanco-Ulate, B., Yang, L., Labavitch, J. M., Bennett, A. B., and Powell, A. L. T. (2009). Ripening-regulated susceptibility of tomato fruit to botrytis cinerea requires nor but not rin or ethylene. Plant Physiol. 150, 1434-1449. doi: 10.1104/pp.109.138701

Cantu, D., Vicente, A. R., Greve, L. C., Dewey, F. M., Bennett, A. B., Labavitch, J. M., et al. (2008a). The intersection between cell wall disassembly, ripening, and fruit susceptibility to Botrytis cinerea. Proc. Natl. Acad. Sci. U.S.A. 105, 859-864. doi: 10.1073/pnas.0709813105

Cantu, D., Vicente, A. R., Labavitch, J. M., Bennett, A. B., and Powell, A. L. (2008b). Strangers in the matrix: plant cell walls and pathogen susceptibility. Trends Plant Sci. 13, 610-617. doi: 10.1016/j.tplants.2008.09.002

Caprari, C., Bergmann, C., Migheli, Q., Salvi, G., Albersheim, P., Darvill, A., et al. (1993). Fusarium moniliforme secretes four endopolygalacturonases derived from a single gene product. Physiol. Mol. Plant Pathol. 43, 453-462. doi: 10.1006/pmpp.1993.1073

Celio, G. J., Mims, C. W., and Richardson, E. A. (2004). Ultra-structure and immuno cytochemistry of the host-pathogen interface in poinsettia leaves infected with powdery mildew. Can. J. Bot. 82, 421-429. doi: 10.1139/b04-019

Chassot, C., and Metraux, J. P. (2005). The cuticle as source of signals for plant defense. Plant Biosyst. 139, 28-31. doi: 10.1080/11263500500056344

Chassot, C., Nawrath, C., and Metraux, J. P. (2007). Cuticular defects lead to full immunity to a major plant pathogen. Plant J. 49, 972-980. doi: 10.1111/j.1365313X.2006.03017.x

Chen, M. H., Sheng, J., Hind, G., Handa, A. K., and Citovsky, V. (2000). Interaction between the tobacco mosaic virus movement protein and host cell pectin methylesterases is required for viral cell-to-cell movement. EMBO J. 19, 913-920. doi: 10.1093/emboj/19.5.913
D’Ovidio, R., Mattei, B., Roberti, S., and Bellincampi, D. (2004). Polygalacturonases, polygalacturonase-inhibiting proteins and pectic oligomers in plant-pathogen interactions. Biochim. Biophys. Acta 1696, 237-244. doi: 10.1016/j.bbapap.2003.08.012

Dangl, J. L., Horvath, D. M., and Staskawicz, B. J. (2013). Pivoting the plant immune system from dissection to deployment. Science 341, 746-751. doi: $10.1126 /$ science. 1236011

Daudi, A., Cheng, Z. Y., O’Brien, J. A., Mammarella, N., Khan, S., Ausubel, F. M., et al. (2012). The apoplastic oxidative burst peroxidase in arabidopsis is a major component of pattern-triggered immunity. Plant Cell 24, 275-287. doi: $10.1105 /$ tpc.111.093039

Davis, E. L., Hussey, R. S., and Baum, T. J. (2004). Getting to the roots of parasitism by nematodes. Trends Parasitol. 20, 134-141. doi: 10.1016/j.pt.2004.01.005

Davis, E. L., Hussey, R. S., Mitchum, M. G., and Baum, T. J. (2008). Parasitism proteins in nematode-plant interactions. Curr. Opin. Plant Biol. 11, 360-366. doi: 10.1016/j.pbi.2008.04.003

Deepak, S., Shailasree, S., Kini, R. K., Muck, A., Mithofer, A., and Shetty, S. H. (2010). Hydroxyproline-rich glycoproteins and plant defense. J. Phytopathol. 158, 585-593. doi: 10.1111/j.1439-0434.2010.01669.x

De Lorenzo, G., Brutus, A., Savatin, D. V., Sicilia, F., and Cervone, F. (2011). Engineering plant resistance by constructing chimeric receptors that recognize damage-associated molecular patterns (DAMPs). FEBS Lett. 585, 1521-1528. doi: 10.1016/j.febslet.2011.04.043

Di Matteo, A., Giovane, A., Raiola, A., Camardella, L., Bonivento, D., De Lorenzo, G., et al. (2005). Structural basis for the interaction between pectin methylesterase and a specific inhibitor protein. Plant Cell 17, 849-858. doi: $10.1105 /$ tpc. 104.028886

Dorokhov, Y. L., Komarova, T. V., Petrunia, I. V., Frolova, O. Y., Pozdyshev, D. V., and Gleba, Y. Y. (2012). Airborne signals from a wounded leaf facilitate viral spreading and induce antibacterial resistance in neighboring plants. PLoS Pathog. 8:e1002640. doi: 10.1371/journal.ppat.1002640

Ellinger, D., Naumann, M., Falter, C., Zwikowics, C., Jamrow, T., Manisseri, C., et al. (2013). Elevated early callose deposition results in complete penetration resistance to powdery mildew in Arabidopsis. Plant Physiol. 161, 1433-1444. doi: 10.1104/pp.112.211011

Ellis, C., Karafyllidis, I., Wasternack, C., and Turner, J. G. (2002). The Arabidopsis mutant cev1 links cell wall signaling to jasmonate and ethylene responses. Plant Cell 14, 1557-1566. doi: 10.1105/tpc.002022

Ellis, C., and Turner, J. G. (2001). The Arabidopsis mutant cev1 has constitutively active jasmonate and ethylene signal pathways and enhanced resistance to pathogens. Plant Cell 13, 1025-1033. doi: 10.1105/tpc.13.5.1025

Eynck, C., Seguin-Swartz, G., Clarke, W. E., and Parkin, I. A. P. (2012). Monolignol biosynthesis is associated with resistance to Sclerotinia sclerotiorum in Camelina sativa. Mol. Plant Pathol. 13, 887-899. doi: 10.1111/j.1364-3703.2012.00798.x

Feng, J., Wang, F., Hughes, G. R., Kaminskyj, S., and Wei, Y. D. (2011). An important role for secreted esterase in disease establishment of the wheat powdery mildew fungus Blumeria graminis f. sp tritici. Can. J. Microbiol. 57, 211-216. doi: 10.1139/W10-120

Ferrari, S., Galletti, R., Pontiggia, D., Manfredini, C., Lionetti, V., Bellincampi, D., et al. (2008). Transgenic expression of a fungal endo-polygalacturonase increases plant resistance to pathogens and reduces auxin sensitivity. Plant Physiol. 146, 669-681. doi: 10.1104/pp.107.109686

Ferrari, S., Savatin, D. V., Sicilia, F., Gramegna, G., Cervone, F., and De Lorenzo, G. (2013). Oligogalacturonides: plant damage-associated molecular patterns and regulators of growth and development. Front. Plant Sci. 4:49. doi: 10.3389/fpls.2013.00049

Ferrari, S., Sella, L., Janni, M., Favaron, F., and D’Ovidio, R. (2012). Transgenic expression of polygalacturonase-inhibiting proteins in Arabidopsis and wheat increases resistance to the flower pathogen Fusarium graminearum. Plant Biol. (Stuttg.) 14, 31-38. doi: 10.1111/j.1438-8677.2011.00449.x

Flors, V., Leyva, M. D., Vicedo, B., Finiti, I., Real, M. D., Garcia-Agustin, P., et al. (2007). Absence of the endo-beta-1,4-glucanases Cell and Cel2 reduces susceptibility to Botrytis cinerea in tomato. Plant J. 52, 1027-1040. doi: 10.1111/j.1365-313X.2007.03299.x

Flors, V., Ton, J., van Doorn, R., Jakab, G., Garcia-Agustin, P., and Mauch-Mani, B. (2008). Interplay between JA, SA and ABA signalling during basal and induced resistance against Pseudomonas syringae and Alternaria brassicicola. Plant J. 54, 81-92. doi: 10.1111/j.1365-313X.2007.03397.x 
Gallego-Giraldo, L., Jikumaru, Y., Kamiya, Y., Tang, Y. H., and Dixon, R. A. (2011). Selective lignin downregulation leads to constitutive defense response expression in alfalfa (Medicago sativa L.). New Phytol. 190, 627-639. doi: 10.1111/j.14698137.2010.03621.x

Galletti, R., Denoux, C., Gambetta, S., Dewdney, J., Ausubel, F. M., De Lorenzo, G., et al. (2008). The AtrbohD-mediated oxidative burst elicited by oligogalacturonides in Arabidopsis is dispensable for the activation of defense responses effective against Botrytis cinerea. Plant Physiol. 148, 1695-1706. doi $10.1104 / \mathrm{pp} .108 .127845$

Gille, S., and Pauly, M. (2012). O-acetylation of plant cell wall polysaccharides. Front. Plant Sci. 3:12. doi: 10.3389/fpls.2012.00012

Giraldo, M. C., and Valent, B. (2013). Filamentous plant pathogen effectors in action. Nat. Rev. Microbiol. 11, 800-814. doi: 10.1038/nrmicro3119

Hamann, T. (2012). Plant cell wall integrity maintenance as an essential component of biotic stress response mechanisms. Front. Plant Sci. 3:77. doi $10.3389 /$ fpls.2012.00077

Hauck, P., Thilmony, R., and He, S. Y. (2003). A Pseudomonas syringae type III effector suppresses cell wall-based extracellular defense in susceptible Arabidopsis plants. Proc. Natl. Acad. Sci. U.S.A. 100, 8577-8582. doi: 10.1073/pnas.1431173100

Hematy, K., Sado, P. E., Van Tuinen, A., Rochange, S., Desnos, T., Balzergue, S., et al. (2007). A receptor-like kinase mediates the response of Arabidopsis cells to the inhibition of cellulose synthesis. Curr. Biol. 17, 922-931. doi: 10.1016/j.cub.2007.05.018

Herbert, C., O’Connell, R., Gaulin, E., Salesses, V., Esquerre-Tugaye, M. T., and Dumas, B. (2004). Production of a cell wall-associated endopolygalacturonase by Colletotrichum lindemuthianum and pectin degradation during bean infection. Fungal Genet. Biol. 41, 140-147. doi: 10.1016/j.fgb.2003. 09.008

Hernandez-Blanco, C., Feng, D. X., Hu, J., Sanchez-Vallet, A., Deslandes, L., Llorente, F., et al. (2007). Impairment of cellulose synthases required for Arabidopsis secondary cell wall formation enhances disease resistance. Plant Cell 19, 890-903. doi: 10.1105/tpc.106.048058

Hewezi, T., Howe, P., Maier, T. R., Hussey, R. S., Mitchum, M. G., Davis E. L., et al. (2008). Cellulose binding protein from the parasitic nematode Heterodera schachtii interacts with Arabidopsis pectin methylesterase: cooperative cell wall modification during parasitism. Plant Cell 20, 3080-3093. doi: 10.1105/tpc.108.063065

Hok, S., Attard, A., and Keller, H. (2010). Getting the most from the host: how pathogens force plants to cooperate in disease. Mol. Plant Microbe Interact. 23, 1253-1259. doi: 10.1094/MPMI-04-10-0103

Jacobs, A. K., Lipka, V., Burton, R. A., Panstruga, R., Strizhov, N., Schulze-Lefert, P., et al. (2003). An Arabidopsis callose synthase, GSL5, is required for wound and papillary callose formation. Plant Cell 15, 2503-2513. doi: 10.1105/tpc.016097

Juge, N. (2006). Plant protein inhibitors of cell wall degrading enzymes. Trends Plant Sci. 11, 359-367. doi: 10.1016/j.tplants.2006.05.006

King, B. C., Waxman, K. D., Nenni, N. V., Walker, L. P., Bergstrom, G. C., and Gibson, D. M. (2011). Arsenal of plant cell wall degrading enzymes reflects host preference among plant pathogenic fungi. Biotechnol. Biofuels 4:4. doi: 10.1186/1754-68344-4

Komarova, T. V., Sheshukova, E. V., and Dorokhov, Y. L. (2014). Cell wall methanol as a signal in plant immunity. Front. Plant Sci. 5:101. doi: 10.3389/fpls.2014.00101

Laluk, K., and Mengiste, T. (2010). Necrotroph attacks on plants: wanton destruction or covert extortion? Arabidopsis Book 8:e0136. doi: 10.1199/tab.0136

Lionetti, V., Cervone, F., and Bellincampi, D. (2012). Methyl esterification of pectin plays a role during plant-pathogen interactions and affects plant resistance to diseases. J. Plant Physiol. 169, 1623-1630. doi: 10.1016/j.jplph.2012. 05.006

Lionetti, V., Raiola, A., Camardella, L., Giovane, A., Obel, N., Pauly, M., et al. (2007). Overexpression of pectin methylesterase inhibitors in Arabidopsis restricts fungal infection by Botrytis cinerea. Plant Physiol. 143, 1871-1880. doi: 10.1104/pp.106.090803

Lionetti, V., Raiola, A., Cervone, F., and Bellincampi, D. (2013). Transgenic expression of pectin methylesterase inhibitors limits tobamovirus spread in tobacco and Arabidopsis. Mol. Plant Pathol. 15, 265-274. doi: 10.1111/mpp. 12090

Llorente, F., Alonso-Blanco, C., Sanchez-Rodriguez, C., Jorda, L., and Molina, A. (2005). ERECTA receptor-like kinase and heterotrimeric G protein from
Arabidopsis are required for resistance to the necrotrophic fungus Plectosphaerella cucumerina. Plant J. 43, 165-180. doi: 10.1111/j.1365-313X.2005. 02440.x

Luna, E., Pastor, V., Robert, J., Flors, V., Mauch-Mani, B., and Ton, J. (2011). Callose deposition: a multifaceted plant defense response. Mol. Plant Microbe Interact. 24, 183-193. doi: 10.1094/MPMI-07-10-0149

Manabe, Y., Nafisi, M., Verhertbruggen, Y., Orfila, C., Gille, S., Rautengarten, C., et al. (2011). Loss-of-function mutation of reduced wall acetylation2 in Arabidopsis leads to reduced cell wall acetylation and increased resistance to Botrytis cinerea. Plant Physiol. 155, 1068-1078. doi: 10.1104/pp.110.168989

Mattei, B., Raiola, A., Caprari, C., Federici, L., Bellincampi, D., De Lorenzo, G., et al. (2002) "Studies on plant inhibitors of pectin modifying enzymes: polygalacturonase-inhibiting protein (PGIP) and pectin methylesterase inhibitor (PMEI)," in Carbohydrate Bioengineering Interdisciplinary approaches, eds T. T. Teeri, B. Svensson, H. J. Gilbert, and T. Feizi (CambridgeRoyal Society of Chemistry), 160-167.

Moscetti, I., Tundo, S., Janni, M., Sella, L., Gazzetti, K., Tauzin, A., et al. (2013). Constitutive expression of the xylanase inhibitor TAXI-III delays fusarium head blight symptoms in durum wheat transgenic plants. Mol. Plant Microbe Interact. 26, 1464-1472. doi: 10.1094/MPMI-04-13-0121-R

Noda, J., Brito, N., and González, C. (2010). The Botrytis cinerea xylanase Xyn11A contributes to virulence with its necrotizing activity, not with its catalytic activity. BMC Plant Biol. 10, 1-15 doi: 10.1186/1471-2229-10-38

O'Brien, J. A., Daudi, A., Butt, V. S., and Bolwell, G. P. (2012). Reactive oxygen species and their role in plant defence and cell wall metabolism. Planta 236, 765-779. doi: 10.1007/s00425-012-1696-9

Passardi, F., Penel, C., and Dunand, C. (2004). Performing the paradoxical: how plant peroxidases modify the cell wall. Trends Plant Sci. 9, 534-540. doi: 10.1016/j.tplants.2004.09.002

Pogorelko, G., Lionetti, V., Bellincampi, D., and Zabotina, O. (2013a). Cell wall integrity: Targeted post-synthetic modifications to reveal its role in plant growth and defense against pathogens. Plant Signal. Behav. 8, 1-8. doi: 10.4161/psb.25435

Pogorelko, G., Lionetti, V., Fursova, O., Sundaram, R. M., Qi, M. S., Whitham, S. A., et al. (2013b). Arabidopsis and Brachypodium distachyon transgenic plants expressing Aspergillus nidulans acetylesterases have decreased degree of polysaccharide acetylation and increased resistance to pathogens. Plant Physiol. 162, 9-23. doi: 10.1104/pp.113.214460

Prins, T. W., Tudzynski, P., Von Tiedemann, A., Tudzynski, B., ten Have, A., Hansen, M. E., et al. (2000). "Infection strategies of Botrytis cinerea and related necrotrophic pathogens," in Fungal Pathology, ed. J. Kronstad (Dordrecht: Kluwer Academic Publishers), 33-64. doi: 10.1007/978-94-015-9546-9_2

Raiola, A., Camardella, L., Giovane, A., Mattei, B., De Lorenzo, G., Cervone, F., et al. (2004). Two Arabidopsis thaliana genes encode functional pectin methylesterase inhibitors. FEBS Lett. 557, 199-203. doi: 10.1016/S0014-5793(03) 01491-1

Raiola, A., Lionetti, V., Elmaghraby, I., Immerzeel, P., Mellerowicz, E. J., Salvi, G., et al. (2011). Pectin methylesterase is induced in Arabidopsis upon infection and is necessary for a successful colonization by necrotrophic pathogens. Mol. Plant Microbe Interact. 24, 432-440. doi: 10.1094/MPMI-07-10-0157

Ramirez, V., Agorio, A., Coego, A., Garcia-Andrade, J., Hernandez, M. J., Balaguer, B., et al. (2011). MYB46 modulates disease susceptibility to Botrytis cinerea in Arabidopsis. Plant Physiol. 155, 1920-1935. doi: 10.1104/pp.110. 171843

Reca, I. B., Lionetti, V., Camardella, L., D’Avino, R., Giardina, T., Cervone, F., et al. (2012). A functional pectin methylesterase inhibitor protein (SolyPMEI) is expressed during tomato fruit ripening and interacts with PME-1. Plant Mol. Biol. 79, 429-442. doi: 10.1007/s11103-012-9921-2

Rocchi, V., Janni, M., Bellincampi, D., Giardina, T., and D’Ovidio, R. (2011). Intron retention regulates the expression of pectin methylesterase inhibitor (Pmei) genes during wheat growth and development. Plant Biol. 14, 365-373. doi: 10.1111/j.1438-8677.2011.00508.x

Ron, M., and Avni, A. (2004). The receptor for the fungal elicitor ethylene-inducing xylanase is a member of a resistance-like gene family in tomato. Plant Cell 16, 1604-1615. doi: 10.1105/tpc.022475

Sanchez-Rodriguez, C., Estevez, J. M., Llorente, F., Hernandez-Blanco, C., Jorda, L., Pagan, I., et al. (2009). The ERECTA receptor-like kinase regulates cell wallmediated resistance to pathogens in Arabidopsis thaliana. Mol. Plant Microbe Interact. 22, 953-963. doi: 10.1094/MPMI-22-8-0953 
Sattler, S. E., and Funnell-Harris, D. L. (2013). Modifying lignin to improve bioenergy feedstocks: strengthening the barrier against pathogens? Front. Plant Sci. 4:70. doi: 10.3389/fpls.2013.00070

Sella, L., Gazzetti, K., Faoro, F., Odorizzi, S., D’Ovidio, R., Schafer, W., et al. (2013). A Fusarium graminearum xylanase expressed during wheat infection is a necrotizing factor but is not essential for virulence. Plant Physiol. Biochem. 64, 1-10. doi: 10.1016/j.plaphy.2012.12.008

Spadoni, S., Zabotina, O., Di Matteo, A., Mikkelsen, J. D., Cervone, F., DL, G., et al. (2006). Polygalacturonase-inhibiting protein (PGIP) interacts with pectin through a binding site formed by four clustered residues of arginine and lysine. Plant Physiol. 141, 557-564. doi: 10.1104/pp.106.076950

Taurino, M., Abelenda, J. A., Rio-Alvarez, I., Navarro, C., Vicedo, B., Farmaki, T., etal. (2014). Jasmonate-dependent modifications of the pectin matrix during potato development function as a defense mechanism targeted by Dickeya dadantii virulence factors. Plant J. 77, 418-429. doi: 10.1111/tpj. 12393

Ton, J., and Mauch-Mani, B. (2004). Beta-amino-butyric acid-induced resistance against necrotrophic pathogens is based on ABA-dependent priming for callose. Plant J. 38, 119-130. doi: 10.1111/j.1365-313X.2004.02028.x

Udatha, D. B. R. K., Mapelli, V., Panagiotou, G., and Olsson, L. (2012). Common and distant structural characteristics of feruloyl esterase families from Aspergillus oryzae. PLoS ONE 7:e39473. doi: 10.1371/journal.pone.0039473

Underwood, W. (2012). The plant cell wall: a dynamic barrier against pathogen invasion. Front. Plant Sci. 3:85. doi: 10.3389/fpls.2012.00085

Vanholme, B., De Meutter, J., Tytgat, T., Van Montagu, M., Coomans, A., and Gheysen, G. (2004). Secretions of plant-parasitic nematodes: a molecular update. Gene 332, 13-27. doi: 10.1016/j.gene.2004.02.024

Vogel, J. P., Raab, T. K., Schiff, C., and Somerville, S. C. (2002). PMR6, a pectate lyase-like gene required for powdery mildew susceptibility in Arabidopsis. Plant Cell 14, 2095-2106. doi: 10.1105/tpc.003509

Vogel, J. P., Raab, T. K., Somerville, C. R., and Somerville, S. C. (2004). Mutations in PMR5 result in powdery mildew resistance and altered cell wall composition. Plant J. 40, 968-978. doi: 10.1111/j.1365-313X.2004.02264.x

Voigt, C. A. (2014). Callose-mediated resistance to pathogenic intruders in plant defense-related papillae. Front. Plant Sci. 5:168. doi: 10.3389/fpls.2014. 00168

Volpi, C., Janni, M., Lionetti, V., Bellincampi, D., Favaron, F., and D'Ovidio, R. (2011). The ectopic expression of a pectin methyl esterase inhibitor increases pectin methyl esterification and limits fungal diseases in wheat. Mol. Plant Microbe Interact. 24, 1012-1019. doi: 10.1094/MPMI-01-11-0021

Wieczorek, K., Golecki, B., Gerdes, L., Heinen, P., Szakasits, D., Durachko, D. M., et al. (2006). Expansins are involved in the formation of nematode-induced syncytia in roots of Arabidopsis thaliana. Plant J. 48, 98-112. doi: 10.1111/j.1365313X.2006.02856.X
Wieczorek, K., Hofmann, J., Blochl, A., Szakasits, D., Bohlmann, H., and Grundler, F. M. W. (2008). Arabidopsis endo-1,4-beta-glucanases are involved in the formation of root syncytia induced by Heterodera schachtii. Plant J. 53, 336-351. doi: 10.1111/j.1365-313X.2007.03340.x

Williamson, V. M., and Kumar, A. (2006). Nematode resistance in plants: the battle underground. Trends Genet. 22, 396-403. doi: 10.1016/j.tig.2006.05.003

Wilson, R. A., and Talbot, N. J. (2009). Under pressure: investigating the biology of plant infection by Magnaporthe oryzae. Nat. Rev. Microbiol. 7, 185-195. doi: 10.1038/nrmicro2032

Xu, L., Zhu, L. F., Tu, L. L., Liu, L. L., Yuan, D. J., Jin, L., et al. (2011). Lignin metabolism has a central role in the resistance of cotton to the wilt fungus Verticillium dahliae as revealed by RNA-Seq-dependent transcriptional analysis and histochemistry. J. Exp. Bot. 62, 5607-5621. doi: 10.1093/jxb/err245

Zhang, L., Kars, I., Essenstam, B., Liebrand, T. W., Wagemakers, L., Elberse, J., et al. (2014). Fungal endopolygalacturonases are recognized as microbeassociated molecular patterns by the Arabidopsis receptor-like protein responsiveness to Botrytis polygalacturonases1. Plant Physiol. 164, 352-364. doi: 10.1104/pp.113.230698

Zhao, Z. T., Liu, H. Q., Wang, C. F., and Xu, J. R. (2013). Comparative analysis of fungal genomes reveals different plant cell wall degrading capacity in fungi. $B M C$ Genomics 14:274. doi: 10.1186/1471-2164-14-274

Zhong, R., Richardson, E. A., and Ye, Z. H. (2007). The MYB46 transcription factor is a direct target of SND1 and regulates secondary wall biosynthesis in Arabidopsis. Plant Cell 19, 2776-2792. doi: 10.1105/tpc.107.053678

Conflict of Interest Statement: The Review Editor, Dr Ferrari, declares that, despite being affiliated to the same institution as authors Dr Daniela Bellincampi and Dr Felice Cervone, the review process was handled objectively. The authors declare that the research was conducted in the absence of any commercial or financial relationships that could be construed as a potential conflict of interest.

Received: 21 March 2014; paper pending published: 10 April 2014; accepted: 06 May 2014; published online: 28 May 2014.

Citation: Bellincampi D, Cervone F and Lionetti V (2014) Plant cell wall dynamics and wall-related susceptibility in plant-pathogen interactions. Front. Plant Sci. 5:228. doi: 10.3389/fpls.2014.00228

This article was submitted to Plant-Microbe Interaction, a section of the journal Frontiers in Plant Science.

Copyright (C) 2014 Bellincampi, Cervone and Lionetti. This is an open-access article distributed under the terms of the Creative Commons Attribution License (CC BY). The use, distribution or reproduction in other forums is permitted, provided the original author(s) or licensor are credited and that the original publication in this journal is cited, in accordance with accepted academic practice. No use, distribution or reproduction is permitted which does not comply with these terms. 